\title{
Ronald Bogue: a monument
}

\section{by Catarina Pombo Nabais ${ }^{1}$}

Ronald Bogue's Deleuze and Guattari. Critics of the Twentieth Century, New York and London: Routledge, 1989, was the first book on Deleuze and Guattari published in English. He belongs to the first group of scholars who deeply and extensively commented Deleuze and Guattari's work in EUA². By doing so, he brought novelty to American academia. He did it in times when Derrida and Foucault were the most noticed philosophers in EUA. Even if their's deconstruction and archeology proposals were studied, not in Philosophy departments dominated as they were by analytical philosophy - but only in literature and social sciences departments. So, bringing Deleuze and Guattari to the EUA was much more than simple curiosity. It was an act of courage, the affirmative gesture of introducing a new radical way of thinking.

This is even more valuable if we think that Deleuze is a philosopher with an enormous and extensive work, having written about a huge range of philosophical domains such as ethics, politics, aesthetics. And in all these areas Ronald Bogue gave us comments and interpretations able to enrich and clarify Deleuze's theses. Deleuze is a monument in Philosophy and Ronald Bogue is also a monument because he dedicated himself to write about Deleuze's work in all its extension: from ethics to politics, passing through his extensive Aesthetics: cinema, theater, literature, painting, music... To analyze all this fields with such an intense look is monumental!

But Ron is also a monument because of the way he did it: he faces the most complex concepts and theses of Deleuze and Guattari's work and turns them easy to understand. His comments and interpretations are never a reductionist simplification of Deleuze and Guattari's strongly innovative theses but a clarifying act of understanding. Ron's analyses are intense and meticulous. This is one of the biggest qualities of a critic and of a teacher: to analyze complex

\footnotetext{
$1 \mathrm{PhD}$ in philosophy by University of Paris VIII, Vincennes - Saint-Denis, under the supervision of Jacques Rancière, awarded with the highest distinction for a PhD thesis in France, 2007, I published my first book in 2013, Deleuze: Philosophie et Littérature, Paris: L'Harmattan. Since 2007, I have been a FCT Post-Doc Researcher at the Centre of Philosophy of Science of University of Lisbon (CFCUL) where I am the coordinator of the Research Line "Science-ArtPhilosophy Laboratory" (SAP LAB).

${ }^{2}$ As well as Charles Stivale and Paul Patton who had already published two important texts in SubStance: A Review of Theory and Literary Criticism, ns. 44/45 (1984): “Gilles Deleuze" where Stivale was the Guest Editor and Patton published the article "Conceptual politics and the war-machine in Mille Plateaux" (pp. 61-80).
} 
concepts and hard philosophical problems and to explain them in a simple way without simplifying the complexity of the theories. Simple doesn't mean lack of deepness. On the contrary, simple means clear. That is the way Ron worked out Deleuze: deep AND clear. Ron challenges himself by facing the deepest parts of Deleuze and Guattari in a clear writing. That is why Ron is such a luminous thinker and precious writer. He is a deep thinker with a very clear way of writing.

Ron is not only a monumental figure in Deleuze Studies but all his work is a monument to Deleuze. Ron has marked deeply and forever the understanding of Deleuze's work.

Another thing that is absolutely fascinating and rare in Ron's approach to Deleuze is the fact that he is critical but devoted. I explain: Ron loves Deleuze and Guattari and his books are a declaration of love instead a mere critic of Deleuze and Guattari's work. We all know that in its Greek definition, philosophy is a matter of love: to love knowledge, to love wisdom and to love the search for truth (says Platon) or to love the confrontation with a problem, to love the search for signs, to love someone in a masochist jealousy, suffer and pain, or even to love and make babies in the back (says Deleuze against Platon). Anyway. Now, and above all, Ron loves Deleuze.

Ron is very serious in his work. But, further that, he almost carries the collective mission of sharing his love and total admiration for Deleuze and, at the same time, of explaining the most detailed and complex parts of Deleuze's work. Bogue has explained us all about it! More than intelligent and accurate, Ron's analyses are transparent and honest. Ron really and truly wants to understand Deleuze and to share the clear understanding he could reach with his readers. Ron thinks with - and makes us all think with - Deleuze and Guattari.

When I did my PhD (as well as Ron, I also did my PhD on philosophy of literature), Ron's books became for me a kind of a Bible to understand Deleuze ${ }^{3}-$ I should even say a familiar Bible, because my daughter, who was a little child at that time, marked all Ron's books with funny

\footnotetext{
${ }^{3}$ I finished my PhD at the end of 2006, so at that time I only had access to Ronald Bogue's Deleuze and Guattari. Critics of the Twentieth Century, New York and London: Routledge, 1989; Deleuze on Music, Painting and the Arts, New York and London: Routledge, 2003; Deleuze on Cinema, New York and London: Routledge, 2003 and Deleuze's Wake: Tributes and Tributaries, Albany: SUNY Press, 2004.
} 
stickers and drawings of animals. And, by some mysterious reason or hidden childish wisdom she only did it to Deleuze and Guattari's and, precisely, to Ron's books.

Deleuze on Literature marked my work a lot. In this book, Ron clarifies several distinctions in Deleuze and Guattari's œuvre. Besides being the first to point out the three different editions of Proust et les Signes (Marcel Proust et les Signes 1964, 1970 and 1976) ${ }^{4}$, he clearly distinguishes and maps different political programs in Deleuze's theory of literature from Proust et les Signes to Critique et Clinique. For instance, he analyses the concept of literary machine in Proust et les Signes and in Kafka - Pour une Littérature Mineure, clarifying that "in Kafka, however, the focus is less on the problem of the transversal unity of multiplicity than on the question of the literary machine's effect within the real" ${ }^{5}$. Another example of Ron's chirurgical clarification abilities: "in Anti-Oedipus the Penal Colony torture machine serves Deleuze and Guattari as a useful example of a desiring machine (...). In Kafka, however, the torture apparatus is but one of the machines Deleuze and Guattari examine, and they argue that it is not Kafka's most successful machine (...) its elements are too easily assimilated with an Oedipal structure of father and son"6.

Specifically in literature, in his Deleuze and Literature, Ron was the unique interpreter who have worked Heinrich von Kleist and Carmelo Bene. For me, this was very important. In fact, I may say that I decided to include Bene in my dissertation because of Ron's analysis of Bene. By his detailed analysis, he made me understand how fabulation is a function of minoration and soustraction.

Further, Ron's methodology is truly philosophical. Not only he interprets Deleuze's theses on literature, but he is completely in search of the nature of literature, of its actual effects on reality and of its inner connection to cosmological forces. For instance, in the middle of Ron's analysis of Deleuze and Guattari's theory of literature, the reader is surprised with questions such as: "what does it mean to write?"7 or "How might we see the word in terms of lines?" 8 . In his search, Ron turns readers into his collaborators by spreading a kind of magical light over them and

\footnotetext{
${ }^{4}$ As Ronald Bogue writes: "In his preface to the third edition of Proust and Signs (1976), Deleuze explains that the first part, published as Marcel Proust and Signs in 1964, concerns the 'emission and interpretation of signs', whereas part two, added in a second edition in 1970 and divided into chapters in 1976, concerns the 'production and multiplication of signs themselves'" (Bogue, Ronald, Deleuze and Literature, p. 31).

${ }^{5}$ Bogue, op. cit., p. 59.

${ }^{6}$ Bogue, op. cit., p. 74.

${ }^{7}$ Bogue, op. cit., p. 153.

${ }^{8}$ Bogue, op. cit., p. 156.
} 
turning them more intelligent. Because Ron is more than luminous. As he is deeply committed to make Deleuze shinning, he shares that light over Deleuze in such a clear, deep and intense way, that he turns the reader more intelligent.

But not only in theory of literature or in the making of my PhD Ron had for me a decisive role. Ron continues to be a main source of my understanding of Deleuze. Even now, very recently, when preparing a talk on tattoos, I was fascinated by Ron's analysis of Giotto's (di Bondone) paintings Saint Francis receiving the Stigmata in the context of faciality and stigmata ${ }^{9}$

And of course, Music. If you ever heard a talk of Ron about music, if you ever had the chance to hear him singing (so perfectly as a territorial bird), you feel you are offered a new access to music and to the understanding of refrain as a demarcation of territory.

All I said is not enough. There is something else that is yet more important. We are all looking for an intensive understanding of Deleuze and Guattari's theory of caosmos, of desire, of ecosophy, Spinoza's body power, Nietzsche's intempestif program, Stoic's concept of event, and so on, and so on. But none of these concepts would have a meaning if they were not actualized. And that is precisely what happens with Ronald Bogue: he performs the very actualization of all the concepts he has so carefully and brightfully explained. What I mean is that more than a great scholar and a great teacher, Ron is a great, great person. He writes as an exercise of a minor life, a minor philosophy. His texts are a kind gesture, the genuine gesture of sharing knowledge, of sharing thought and even of sharing doubts. He is a wonderful, generous and modest person, always ready to help the others. This capacity of pure altruism is one of the greatest elements of Ron's personality. This is a very important thing both in life, in philosophy and in academia. Specially nowadays, where neoliberalism has contaminated our way of being in academia. Rather than competing for the most rated article published, we would better promote and improve ways of discussing ideas and sharing knowledge. This is what Ron does with great professionalism, humility and joy.

I met Ron in Prague, 2010. I will never forget the great conversation we had and the way he immediately made me feel appreciated by having a real interest about my work. I must also say that Ron was one of the first scholars to carefully read my book. He wrote me about and

\footnotetext{
${ }^{9}$ Cf. Bogue, Ronald, Deleuze on Music, Painting and the Arts, pp. 95-105.
} 
immediately offered himself to write the Preface to the English Edition. Also, when I organized The Sixth Deleuze Studies Conference in Lisbon, I was happily surprised with the real effort Ron had made working on the specific theme of the conference, which was concentrated on the concept of territory. Ron presented three sessions at the Deleuze Camp and a plenary talk at the conference always on the concept of territory in different perspectives ${ }^{10}$.

The most precious thing about sharing a real friendship with Ron (something that all his readers share, even if they do not know him personally) is that, through his books, by experiencing all the qualities I have talked about (kindness, the joy of sharing, the love for philosophy) new connections with the world are created. Ron is the biggest example I know of truly commitment to philosophy as love, kindness, joy and will of sharing knowledge with everyone. Ron is a great example of philosophy as joy of thought and joy of life: because life is only intense if we turn ideas and concepts into actual modes of being in this world. Ron is the actualization of Deleuze's concept of l'immanence une vie and he shares with us the literature's efficacy of being a real experimentation of life: language is a pragmatics and has real effects in life as speech acts. So, by all his qualities, Ronald Bogue made of his life - a life devoted to Deleuze and Guattari - a political act, in a minor style, as Bene: Ronald Bogue is so humble that his work is the example of the minoration of power structures that, unfortunately, we easily find in academia. And we, as his readers, we have the impression we are catching him in flagrant délit de fabulation in this collective mission of deeply and clearly explaining and thinking with Deleuze and Guattari. One of the best lessons about literature is that literature is political and Ronald Bogue acts politically in the way he writes about Deleuze. So, we may say that one of the biggest effects the work of Ronald Bogue has produced in philosophy and in academia of the recent world is, as Guattari would say, an ecology of mentalities.

\footnotetext{
${ }^{10}$ The plenary talk was entitled "Corporate Movement, the State and the War Machine" (talk presented at the Sixth Annual International Deleuze Studies Conference, University of Lisbon, Portugal, July 9, 2013). The three lectures at the Deleuze Camp were: "Territory and the Refrain", "Messiaen and the Musical Refrain" and "Scoring the Rhizome: Bussotti and the Territorial Refrain" (lectures presented at the Seventh Deleuze Camp, Fábrica Braço de Prata, Lisbon, July 1-5, 2013).
} 